\title{
To be (Masked) or Not to be (Masked) during the Covid-19 Pandemic: A Social and Psychological Double Bind
} \author{
Ireland \\ ${ }^{2}$ Faculty of Medicine, Université catholique de Louvain, Belgium \\ ${ }^{3}$ Université catholique de Louvain, Belgium \\ ${ }^{4}$ Faculty of Psychology, Université catholique de Louvain, Belgium
}

Anne-Frédérique Naviaux ${ }^{1,2^{*}}$, Pascal Janne $e^{3,4}$ and Maximilien Gourdin ${ }^{2,3}$

${ }^{1}$ College of Psychiatrists of Ireland and Health Service Executive (HSE) Summerhill, Community Mental Health Service,

\begin{abstract}
In the context of the exponential growth of the pandemic, everyone has to make some decision: When there is a world shortage of material (screening tests, masks, respirators and vaccine), societal measures are crucial to contain an epidemic. In this context, psychological and behavioral parameters become directly relevant to public health, but can also subject us to a philosophical argument as in Pascal's wager.
\end{abstract}

To be masked or not to be masked during the Covid-19 Pandemic appears then as a social and psychological double bind.

\section{Introduction}

The subject of protective masks, be they professionally or handmade, is omnipresent and concerns healthcare professionals as well as the general population [1,2].

So should you wear one?

In some countries, wearing a mask was made mandatory and you are not expected to choose but only to comply.

But in the vast majority of the rest of the world, especially when considering de-confinement, wearing a mask (or not) remains a social and psychological matter, sometimes to a schizophrenogenic extent:

- If you wear a protective mask, some people will be suspicious of you as it could mean that you have the virus, while depending on their psychological reasoning, others will believe that you are trying to protect yourself and/or your environment.

- If you don't wear a protective mask, you might be perceived as a public menace, especially if you are a healthcare worker.

This means that in both situations, you are partially wrong as you either generate or maintain Covid-phobia and/or Covid-chondria. You can't win!

The same duality applies to healthcare workers: They can be acknowledged (and applauded) as heroes who are saving lives, or they can be attacked by people who consider them as contamination agents.
This is a typical case of "double bind" as per the Palo Alto studies which demonstrated how a schizophrenic patient is often subjected to dual constraints $[3,4]$.

On the positive side, while currently waiting for a vaccine, the world economy, as well as people of good will attempt to produce as many masks as possible; as long as they are effective against coronavirus.

The decision to wear (or not) the mask goes the same way as Pascal's wager [5]: Believing in it is better than not believing in it, so wearing the mask is better than denying its benefit.

\section{References}

1. Colbourn T (2020) COVID-19: Extending or relaxing distancing control measures. The Lancet Public Health 5: e236-e237.

2. Feng $S$, Shen $C$, Xia N, et al. (2020) Rational use of face masks in the COVID-19 pandemic. Lancet Respir Med 8: 434-436.

*Corresponding author: Anne-Frédérique Naviaux, MD, Consultant Psychiatrist \& Consultant Child Psychiatrist Health Service Executive (HSE) Summerhill, Community Mental Health Centre, Wexford, Y35 KC58, Ireland, Tel: +353-0-53-9123899, Fax: +353-0-53-9155900

Accepted: December 12, 2020

Published online: December 14, 2020

Citation: Naviaux AF, Janne P, Gourdin M (2020) To be (Masked) or Not to be (Masked) during the Covid-19 Pandemic: A Social and Psychological Double Bind. Ann Microbiol Res 4(1):112-113 
Citation: Naviaux AF, Janne P, Gourdin M (2020) To be (Masked) or Not to be (Masked) during the Covid-19 Pandemic: A Social and Psychological Double Bind. Ann Microbiol Res 4(1):112-113

3. Bateson G, Jackson DD, Haley J, et al. (1956) Toward a theory of schizophrenia. Behavioral Science 1: 251-264.

4. Schuham Al (1967) The double-bind hypothesis a decade later.
Psychological Bulletin 68: 409-416.

5. Rota M (2017) Pascal's wager. Philosophy Compass 12: e12404.

DOI: $10.36959 / 958 / 578$

Copyright: (c) 2020 Naviaux AF, et al. This is an open-access article distributed under the terms of the Creative Commons Attribution License, which permits unrestricted use, distribution, and reproduction in any medium, provided the original author and source are credited. 